\title{
Anthropology is the discipline but the goal is ethnography
}

\author{
Daniel Miller, University College London
}

In this debate piece, I argue that there is something more important than the discipline of anthropology, and that is the ability of anthropologists to study the world through ethnography and transmit that understanding back to global populations as education. An inwardly directed concern only with our discipline can sometimes constrain both of these tasks.

Keywords: ethnography, anthropology, why we post, open access

Well, I am the fourth speaker and this is intended to be a debate. So given what Tim Ingold has just been saying, it seems to me that I have no choice. The line I must take is that ethnography is in fact the "be-all and end-all" of anthropology. I will therefore try and persuade you that this is indeed the case.

But to do this I will have to start with a different view on the meaning of "ethnography." Tim Ingold has tried to carefully disaggregate the term ethnography from fieldwork or participant observation or method. I understand why he is trying to do this and the advantage to his argument that would bring. The problem is that for generations anthropologists have been using terms such as fieldwork, ethnography, and participant observation as more or less synonymous and in effect as the terms for our method. I suggest therefore that it would be better to accept the colloquial meaning and definition of ethnography and work from there. Unlike Ingold, I will use the term ethnography in the way I think most people routinely use it.

My argument then has to be against the consensus in a different way. Rather than seeing ethnography as mere method whose aim is to contribute to the discipline of anthropology, I want to suggest that we as anthropologists need to regard ethnography as our ultimate goal that we should be striving for.

So first, my own understanding of ethnography, which as with most things for myself right now derives from the recently completed Why we post project, which 
comprised nine simultaneous fifteen-month ethnographies all studying the use and consequences of social media (Miller et al. 2016).

In our project, we call ethnography holistic contextualisation. The point is simply that when we started we had no idea why people post on social media. It might be to do with family, with class, with religion, or with politics. Unless we know something about all of these topics we cannot answer this question. Furthermore, no one lives just on social media-they live everything at once-so ethnography has to have the same integrity as everyday life, which is why most of our work is offline. Ethnography is never just observation because the whole point, for an anthropologist, is that as soon as you make the decision to describe something, with that comes a responsibility to account for what you claim to have observed. Furthermore, at least in our case, we guard against the potential parochialism of ethnography by always working comparatively.

My own model came from the ethnographies I was given when I first learned anthropology, such as the early works of Clifford Geertz (1963a and 1963b). In these books there wasn't much debate with other anthropologists or something abstracted as theory; the strength of his work came from the original insights that helped account for what had been observed, and it is assumed that to the degree this was required, the ethnography would also include any wider knowledge that helped account for the observations such as history or political economy.

A problem for contemporary anthropological practice is that a student may be expected to spend up to a year preparing to study a topic of current anthropological concern, but almost inevitably when they get to their field site this proves to be completely different from what they expected and most of that initial preparation turns out to have been inappropriate. In our project, nobody found what they wanted or what they were looking for. Elisabetta Costa (2016) is a political anthropologist and picked a site on the Syrian-Turkish border, but found for various reasons that other topics such as gender were far more central to the transformations wrought by social media than politics. Nell Haynes (2016) was funded to study indigeneity, but this was not something that was addressed within social media. Xinyuan Wang (2016) assumed social media would be used by Chinese factory workers to communicate with their left-behind families, but by and large it wasn't. In other words, ethnography - ethnography with integrity-is always the humiliation of the anthropologist and I would argue that perhaps we should welcome it also as the humiliation of anthropology itself.

Now why would I welcome this humiliation? I have no desire to detract from anthropology as a discipline. It is wonderful that after a century we can still find new issues and insights and continue to learn from debating the hau. My perspective on the world was transformed by Levi-Straussian structuralism and much else since then. There are brilliant anthropologists who we want to learn about and learn from, but even if we add the entire contribution of all anthropologists that have ever been, that is simply a drop in the ocean of cultural creativity. What we gain from comparative ethnography is the world itself, the totality of human creativity-all the religions, every kinship system, the incredible dynamics of contemporary transformations in the digital age. Anthropology needs to retain that sense of humility with respect the vastly bigger picture that is opened up to us by ethnography. 
My worry is that far from accepting this humility, anthropology is going in the opposite direction of self-absorption. Two examples. We often criticize something called neoliberalism, which has many potential definitions. One of these would be a perspective in which the unit of value has become the isolated individual instead of some wider social or collective value. When I started anthropology, our units of value tended to be The Nuer, The Trobriand Islanders, or the Kwakiutl, but today all the discussion around me seems to be asking whether someone is aligned with Bruno Latour or Nancy Scheper-Hughes or Arjun Appadurai (or is he now too "last year"?). A world of citations and brand-like individual names. I have conducted ethnography of business and I have never encountered a business half as neoliberal, by this definition, as the discipline of anthropology. Anthropology can be important, or self-important, I am not sure it is going to be both.

Similarly, in understanding political economy I see money as pretty useful in everyday life; in fact, I follow Georg Simmel in viewing money as the foundation of human freedom. But once money gets abstracted, fetishized, as capital we encounter all those negative forces analyzed by Karl Marx. Still more abstract is modern finance capital, which doesn't even invest in commerce any more since it is mainly sucking assets up to the levels of its own abstractions. It is the same in anthropology. Ethnography is our engagement with people. You would think then that theory is something we would use to help clarify and explain how we have accounted for what has been observed and that is indeed the way we used theory in our comparative project. But in much of anthropology, theory like capital has become fetishized as a thing in itself, as in "but does your book have enough theory." Instead of helping to explain the world, it is as though the world only exists so anthropologists can exploit it to create the thing they want, which is theory. That is fetishism. Still more abstract are those anthropologists who seem to have no desire to return to ethnography but rather engage from their armchairs with philosophers. They have become our hedge fund managers, trading in anthropological derivatives, which today suck the humanity out of ethnographically led anthropology.

Now why does this matter? I have noticed that the most common definition of the discipline that anthropology students post on Facebook comes from Ruth Benedict and is about making the world safe for human differences. Yet what do we actually do today to secure that goal? When I started anthropology there were loads of TV programs based on ethnography, and people would often bring in anthropology within more popular debates. But all this has declined. We wanted to use our project in school teaching, but I can't apply it to the anthropology "A" level within the school curriculum in Britain, since this is being abandoned owing to lack of demand. Instead, all our current work is with teachers in the sociology "A" level, who incidentally are delighted to have our materials to help with their teaching. This is why we need not just Open Access but openly accessible English (and translations) to turn anthropology into something that actually influences young people around the world. Please note that I am not asking here for “impact," I am asking for global education, as I always thought that education is what academics were supposed to be contributing to. ${ }^{1}$

1. Thanks to open access and accessible language, our initial books have already been downloaded 2,416 times in the Philippines, 1,395 times in Ethiopia, and 1,147 times in Pakistan, with a global total of around 183,000 downloads. 
My concluding point is this: How many Brexits must we live through, where we know that a prime cause of the result was that so far from people gaining a wide appreciation and empathy for other peoples, we see instead a xenophobic resistance to even encountering people from elsewhere? How many Trumps must we live through, where we know this was again a primary cause of his success, before we stand up and state clearly that anthropology has greater responsibilities to the world than just its own intellectual conceit?

This is why I enter a plea for anthropology to accept its humility with respect to ethnography. While I accept all that Signe Howell has argued for the integration between the two, for that same reason, one wants to see anthropologists periodically reimmersed in that humbling experience of ethnography where once again they have to appreciate that the world is always so much more than we can envisage. It is ethnography that keeps us open to the world and provides the insights we return to the world. That is why I would argue that anthropology is the discipline of which we are proud, but the ultimate goal that should define who and what we are is inductive ethnography.

\section{Acknowledgments}

Why We Post was funded by ERC grant 2011-AdG-295486 Socnet.

\section{References}

Costa, Elisabetta. 2016. Social media in southeast Turkey. London: UCL Press.

Geertz, Clifford. 1963a. Agricultural involution: The process of agricultural change in Indonesia. Berkeley: University of California Press.

1963b. Peddlers and princes: Social change and economic modernization in two Indonesian towns. Chicago: University of Chicago Press.

Haynes, Nell. 2016. Social media in northern Chile. London: UCL Press.

Miller, Daniel, Elisabetta Costa, Nell Haynes, Tom McDonald, Razvan Nicolescu, Jolynna Sinanan, Juliano Spyer, ShriramVentkatraman, and Xinyuan Wang. 2016. How the world changed social media. London: UCL Press.

Wang, Xinyuan. 2016. Social media in industrial China. London. UCL Press.

\section{L'anthropologie est une discipline mais le but est l'ethnographie}

Résumé : Dans cette présentation, je soutiens qu'il y a quelque chose de plus important que la discipline anthropologique, à savoir la capacité des anthropologues à étudier le monde grâce à l'ethnographie et à transmettre cette compréhension à la population mondiale en retour sous une forme éducative. Un intérêt exclusivement attentif aux débats internes de notre discipline peut parfois faire obstacle à ces tâches. 
Daniel Miller is Professor of Anthropology at University College London. He is the author/editor of thirty-nine volumes, almost all based upon ethnographic research.

Daniel Miller

Department of Anthropology

University College London

14 Taviton Street

London WC1H OBW

d.miller@ucl.ac.uk 